\title{
Article \\ Hydrologic Restoration of the Lac des Allemands Swamp, Barataria, Louisiana
}

\author{
Gary P. Shaffer ${ }^{1, *}$, Demetra Kandalepas ${ }^{1}$, Nicholas Stevens ${ }^{1}$, Tessera Crockett ${ }^{1}$ and Glen Curole ${ }^{2}$ \\ 1 Department of Biological Sciences, Southeastern Louisiana University, Hammond, LA 70422, USA; \\ demetra.kandalepas@selu.edu (D.K.); nicholas.stevens@selu.edu (N.S.); tessera.crockett@selu.edu (T.C.) \\ 2 Coastal Protection and Restoration Authority of Louisiana, 1440 Tiger Drive, Thibodaux, LA 70301, USA; \\ glen.curole@la.gov \\ * Correspondence: gary.shaffer@selu.edu
}

check for updates

Citation: Shaffer, G.P.; Kandalepas, D.; Stevens, N.; Crockett, T.; Curole, G. Hydrologic Restoration of the Lac des Allemands Swamp, Barataria, Louisiana. Forests 2021, 12, 1074. https://doi.org/10.3390/f12081074

Academic Editors: William H. Conner and Thomas J. Dean

Received: 26 June 2021

Accepted: 4 August 2021

Published: 12 August 2021

Publisher's Note: MDPI stays neutral with regard to jurisdictional claims in published maps and institutional affiliations.

Copyright: (c) 2021 by the authors. Licensee MDPI, Basel, Switzerland. This article is an open access article distributed under the terms and conditions of the Creative Commons Attribution (CC BY) license (https:// creativecommons.org/licenses/by/ $4.0 /)$.

\begin{abstract}
Most of the forested wetlands of coastal Louisiana are in decline, primarily due to impoundment and increased flood duration. The Lac des Allemands swamp of Barataria Basin was a prime example of prolonged inundation prior to hydrologic restoration completed in February of 2018; the swamp had been impounded for over 60 years. To characterize restoration benefits, eight paired $625 \mathrm{~m}^{2}$ permanent sites were established close to and halfway between eight $30 \mathrm{~m} \times 122 \mathrm{~m}$ gaps cut into the spoil bank of Bayou Chevreuil. During 2018, canopy closure increased by $20 \%$. In addition, aboveground production of wood and leaves increased over 2017 from 2018-2020. Furthermore, natural regeneration has occurred annually and many of the seedlings are now approximately $1 \mathrm{~m}$ tall. In conclusion, hydrologic restoration of impounded wetlands in coastal Louisiana is an extremely cost-effective landscape restoration method.
\end{abstract}

Keywords: impoundment; hydrologic restoration; Taxodium distichum; swamp; natural regeneration

\section{Introduction}

Most bald cypress-water tupelo (Taxodium distichum (L.) Rich, Nyssa aquatica (L.)) swamps in coastal Louisiana are degrading [1]. Stressors include saltwater intrusion, nutrient limitation, hydrologic alteration, herbivory, logging, and development. Many wetland restoration projects have been implemented or are being planned in coastal Louisiana. Several of these projects have been designed to alleviate flooding stress in bald cypress-water tupelo swamps $[2,3]$.

One such effort was constructed in the Lac des Allemands swamp, located in the Barataria Basin of southeastern Louisiana. The restoration plan for this effort was written by the senior author of this manuscript in 2011. Shortly thereafter, the project was funded by the Coastal Wetland Planning, Protection, and Restoration Act at $\$ 7.88$ million, but was constructed at under $\$ 500,000$. On average, wetland restoration in coastal Louisiana costs about $\$ 70,000$ per acre [3]; the cost for this project was $\$ 208$ per acre, arguably the lowest cost of landscape restoration in Louisiana history.

The wetlands of Barataria have been studied extensively for over 50 years [4]. In particular, the Lac des Allemands swamp has been studied since the mid-1970s [5]. Swamp aboveground production declined steadily over the next several decades [6,7] and exhibited little natural regeneration. Prior to restoration, this swamp was nearly permanently flooded, preventing seed germination and recruitment of bald cypress and water tupelo [5,8-13].

The hydrologic restoration in the 970 ha Lac des Allemands Swamp provided for preconstruction forested and herbaceous vegetation station establishment during fall of 2016. Monitoring the entire 2017 year provided data for computation of swamp productivity prior to project construction. Monitoring during 2018-2020 enabled us to begin measuring the response of the swamp to hydrologic restoration. The purpose of this study was to 
clearly document the vegetative response of providing hydrologic exchange to a swamp that had been impounded for over 60 years, including natural regeneration events.

\section{Materials and Methods}

\subsection{Study Site}

The Lac des Allemands swamp is located in the Barataria Basin of southeastern Louisiana (Figure 1). This swamp has been impounded for over 60 years, and restoration involved increasing the hydrologic exchange between the swamp and Bayou Chevreuil by creating eight $30 \mathrm{~m} \times 122 \mathrm{~m}$ gaps in the spoil bank. To capture restoration benefits, sixteen project specific forested swamp stations were established in 2016 (Figure 1) prior to the restoration effort.

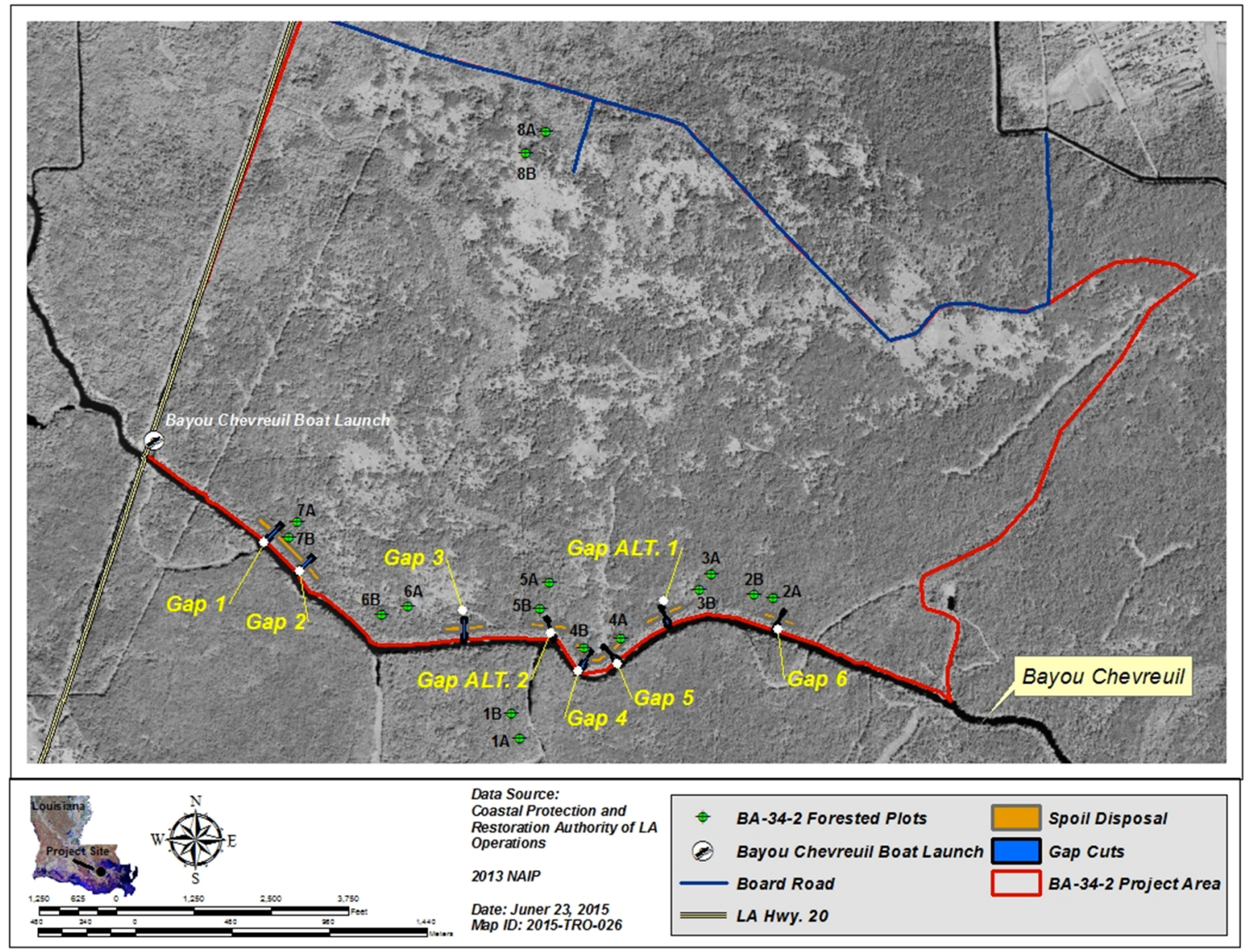

Figure 1. Aerial map showing the location of the sixteen $625 \mathrm{~m}^{2}$ Stations (eight Sites) established in 2016 at the Lac des Allemands swamp restoration project. Locations of the eight gaps are also shown.

The sites were located near and roughly halfway between the restoration gap locations to crisply capture maximum and minimum project benefits, respectively. Stations within sites were located at least $100 \mathrm{~m}$ apart to ensure true replication. In addition, a healthy reference site (Site 1A and 1B) was located on LSU Island and a site was also located near the northern border (Site 8A and 8B, Figure 1), which was conceived unlikely to benefit from the gaps in Bayou Chevreuil.

\subsection{Forested Swamp Vegetation}

The sixteen $625 \mathrm{~m}^{2}(25 \mathrm{~m} \times 25 \mathrm{~m})$ forested swamp stations were sampled from 2016 to 2020. The directional corners (NE, NW, SE, \& SW) of these stations were marked with $3 \mathrm{~m}$ sections of PVC pipe, and UTM NAD 83 coordinates were established at the southeast corner of each station with a differential GPS (DGPS) with sub-meter accuracy. 
The pipe at each of these is painted with three stripes and all 1049 tree tags are pointed at the three-striped pipe of each station. A tag was fastened to each tree with a $3^{\prime \prime}$ deck screw so that the screw could be backed out as the tree gained diameter over the 20-year monitoring effort. In addition, a second screw was placed at the base level of each tag 90 degrees on the backside of each tree to increase accuracy of subsequent annual diameter measurements [14,15]. Each tree also is tagged with one strand of bright survey tape; every other year a second strand of survey tape is fitted or removed from each tree to increase the efficiency of locating and measuring all trees. Trees were identified to species, canopy cover was estimated at each of the four $2 \mathrm{~m} \times 2 \mathrm{~m}$ herbaceous vegetation plots, diameter at breast height (DBH; actually at $2 \mathrm{~m}$ to avoid buttress swell $[14,15])$ was measured for canopy and midstory trees $(\geq 4 \mathrm{~cm}$ diameter). Forested swamp stations were sampled during late fall (October through early December) of 2016-2020. In addition, four $0.25 \mathrm{~m}^{2}$ litterfall traps were randomly deployed at each station once the 2016 canopy leaves had completely fallen from all trees. These traps are swept about every 2 months and roughly monthly during periods of high litterfall until all leaves had fallen (generally mid-March of the following year). The leaves were sorted to the two canopy species, Nyssa aquatic and Taxodium distichum, and a midstory (almost exclusively Acer rubrum var. drummondii), and dried and weighed. Canopy closure was estimated with a microdensitometer at each of the 64 herbaceous plots in the fall of 2016-2020.

\subsection{Herbaceous Vegetation}

Within each of the 16 forested stations, four $4 \mathrm{~m}^{2}(2 \mathrm{~m} \times 2 \mathrm{~m})$ herbaceous plots were sampled to estimate herbaceous vegetation cover by species in $5 \%$ increments $[14,15]$. Four $2 \mathrm{~m}$ PVC stakes permanently mark each plot. Each plot was located $\sim 5 \mathrm{~m}$ from each station corner pole and situated such that no trees are located in any herbaceous plots. Herbaceous plots were sampled each fall of 2016-2020.

\subsection{Soil Strength}

Soil cores were collected during fall of 2017 and spring of 2018. Four cores were taken at each of the 16 stations using a battery-powered impact driver with a sharpened aluminum pipe attached to it that was about $30 \mathrm{~cm}$ long with a diameter of $3.5 \mathrm{~cm}$. The soil cores were drilled to a depth of $10 \mathrm{~cm}$ and all four cores were pooled into a labeled plastic bag. The soil samples were stored in a ventilation oven in the wetlands lab at Southeastern Louisiana University where they were dried for several weeks. Once the moisture had been completely removed from the samples, they were weighed. The dry weight and the volume of the entire soil sample were then used to calculate bulk density.

To calculate the percent organic material within the soil, the samples were burnt in a ceramic kiln at $600^{\circ} \mathrm{F}$ for several hours. After burning off all organic material, the samples were returned to the ventilation oven for $24 \mathrm{~h}$ and re-weighed for mineral weight. The percent organic material was then calculated by comparing the mineral weight to the total dry weight.

\subsection{Data Analysis}

Each year, tree diameter was used to compute aboveground tree wood biomass using published regression formulas [16-18]. Wood production was calculated as the difference in wood biomass per year [19-21]. Wood production per tree was then summed by species category per station and then converted to total aboveground wood production per square meter per year $\left(\mathrm{gm} \mathrm{m}^{-2} \mathrm{y}^{-1}\right)$.

Forest data were analyzed with the GLM procedure of SYSTAT 13 software. For wood net primary production, a repeated measures analysis was performed because of pseudoreplication, and F values are reported as Hotelling-Lawley Trace statistics. Herbaceous data were analyzed using the non-metric multidimensional scaling procedure of Primer 7. Resemblance matrices were computed using Bray-Curtis similarity. 


\section{Results and Discussion}

\subsection{Soil Strength}

The bulk density ranged from $0.052 \mathrm{gm} \mathrm{cm}^{-3}$ at Station $3 B$ to $0.142 \mathrm{gm} \mathrm{cm}^{-3}$ at Station 5B (Table 1) and averaged $0.088 \mathrm{gm} \mathrm{cm}^{-3}\left( \pm 0.006 \mathrm{gm} \mathrm{cm}^{-3}\right.$ s.e.). The percent organic matter ranged from $30.57 \%$ at Station $2 \mathrm{~A}$ to $92.70 \%$ at Station $8 \mathrm{~A}$ and averaged $61.88 \%$ ( $\pm 4.60 \%$ s.e.). These soils are extremely weak and quite similar to those of the far more degraded Maurepas swamp located in the Pontchartrain Basin [14,15]. Soils characterized by high organic content are generally impounded [16-18].

Table 1. Soil bulk density and percent organic matter at the reference site (1) and seven sites located in the Lac des Allemands swamp.

\begin{tabular}{cccc}
\hline Site & Station & Bulk Density $\left(\mathrm{g} / \mathrm{cm}^{3}\right)$ & Percent Organic (\%) \\
\hline \multirow{2}{*}{1} & A & 0.082 & 56.47 \\
\cline { 2 - 4 } & B & 0.075 & 62.98 \\
\cline { 2 - 4 } & A & 0.083 & 30.57 \\
\hline \multirow{2}{*}{3} & B & 0.095 & 38.17 \\
\hline \multirow{2}{*}{4} & A & 0.079 & 72.78 \\
\hline \multirow{2}{*}{5} & B & 0.052 & 76.83 \\
\hline & A & 0.094 & 69.22 \\
\hline \multirow{2}{*}{6} & B & 0.132 & 49.78 \\
\hline & A & 0.087 & 58.25 \\
\hline \multirow{2}{*}{7} & B & 0.142 & 37.01 \\
\hline \multirow{2}{*}{8} & A & 0.073 & 79.10 \\
\hline & B & 0.078 & 67.80 \\
\hline & A & 0.105 & 51.76 \\
\hline & B & 0.113 & 54.84 \\
\hline & A & 0.058 & 92.70 \\
\hline
\end{tabular}

\subsection{Forest Structure}

All trees $\geq 4 \mathrm{~cm}$ diameter were labeled with aluminum tags fastened at roughly $2 \mathrm{~m}$ height to ensure measurements were made above all buttresses [14,15]. In 2017, basal area differed widely between sites $\left(\mathrm{F}_{7,1032}=8.64, p<0.0001\right)$ and tree species $\left(\mathrm{F}_{8,1032}=36.45\right.$, $p<0.0001$ ). In general, basal area averaged $53.78 \mathrm{~m}^{2} \mathrm{ha}^{-1}$ and ranged between $43.14 \mathrm{~m}^{2} \mathrm{ha}^{-1}$ and $69.41 \mathrm{~m}^{2} \mathrm{ha}^{-1}$ (Figure 2), nearly double that of most of the Maurepas swamp [14,15]. Interestingly, several stations in the project area had higher basal areas than the reference site (Figure 2). Although nine woody species were present, Acer rubrum var. drummondii (Hook. And Arn. Ex Nutt.), Nyssa aquatica, and Taxodium distichum accounted for $96.8 \%$ of the stems present. Basal areas of these three species differed widely $\left(\mathrm{F}_{2,991}=122.66\right.$, $p<0.0001$; Figure 3) and was highly inconsistent across sites (interaction $\mathrm{F}_{14,991}=5.59$, $p<0.0001$ ). Basal area of the two main canopy species, T. distichum and N. aquatica, varied in dominance (Figure 3). 


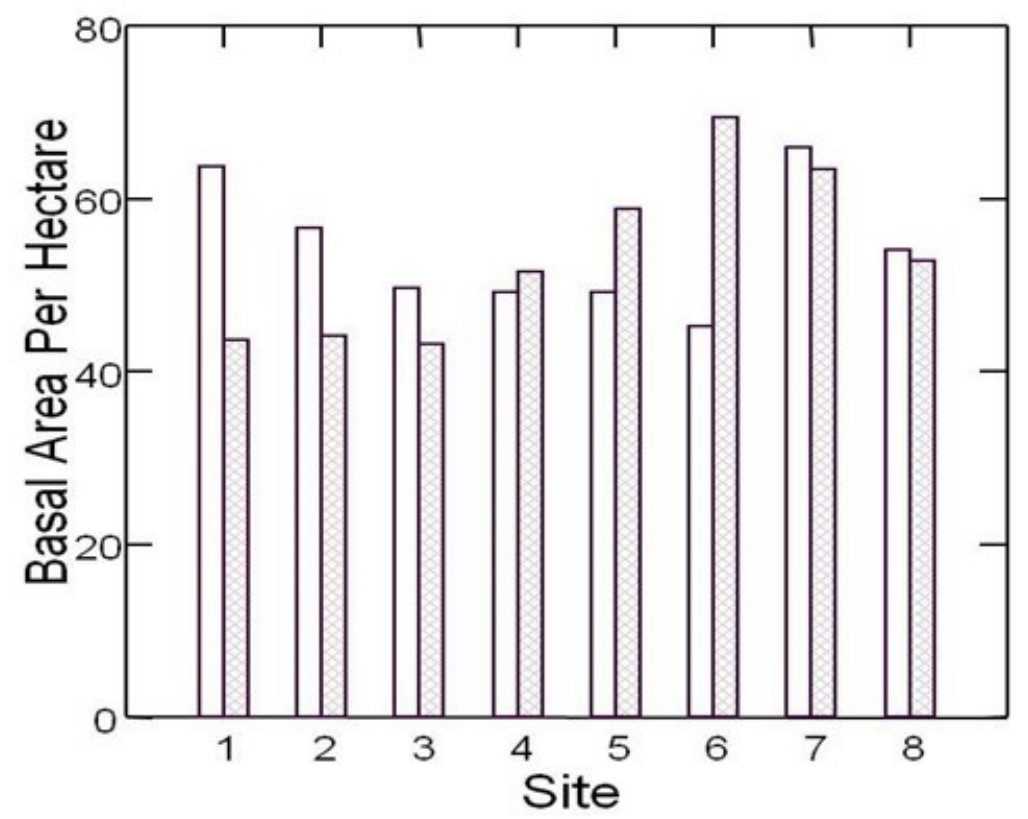

Figure 2. Basal area for stations A (open) and B (hatched) at sites 1-8 in 2017.

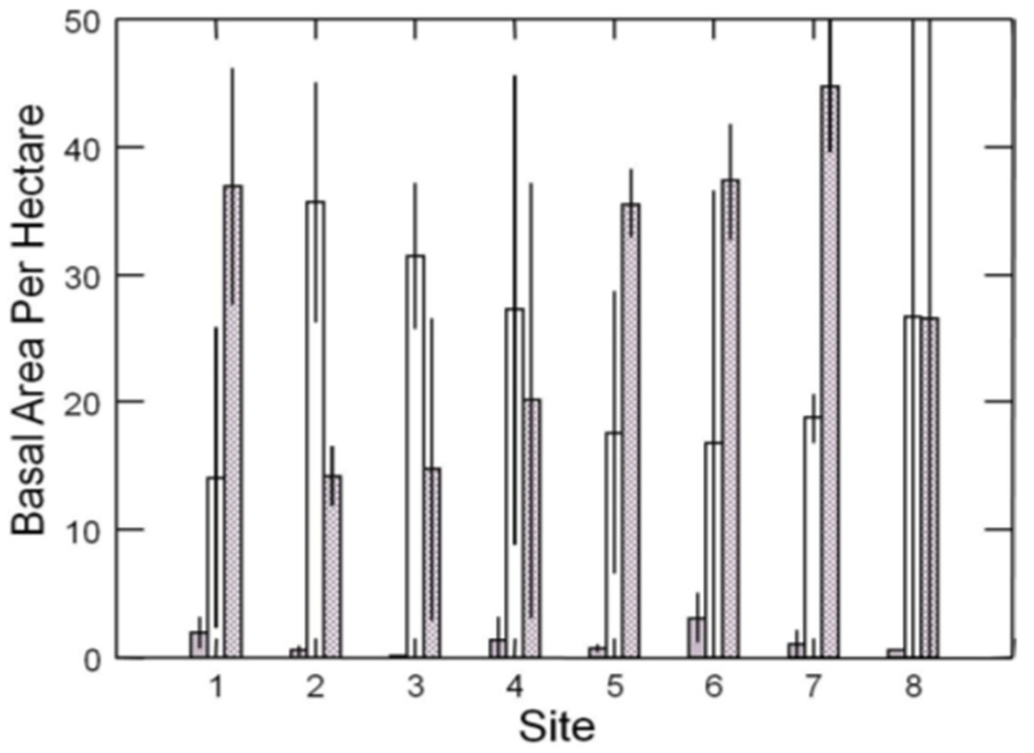

Figure 3. Basal area $\left(\mathrm{m}^{2} \mathrm{ha}^{-1}+\right.$ s.e.) for the three dominant tree species A. rubrum var. drummondii (gray), N. aquatica (open) and T. distichum (hatched) at Sites 1-8 in 2017.

Stem density in 2017 averaged 1012 per hectare and ranged between 528 and 1568 (Figure 4) and was highest at the reference site. This is the same site as Conner and Day's [5,7] "natural" site, which had stem densities ranging between 880 and 990 stems per hectare. Acer rubrum var. drummondii had the greatest number of stems only at Site 7, whereas Nyssa aquatica contained the greatest number of stems at five of the eight sites (Figure 5). 


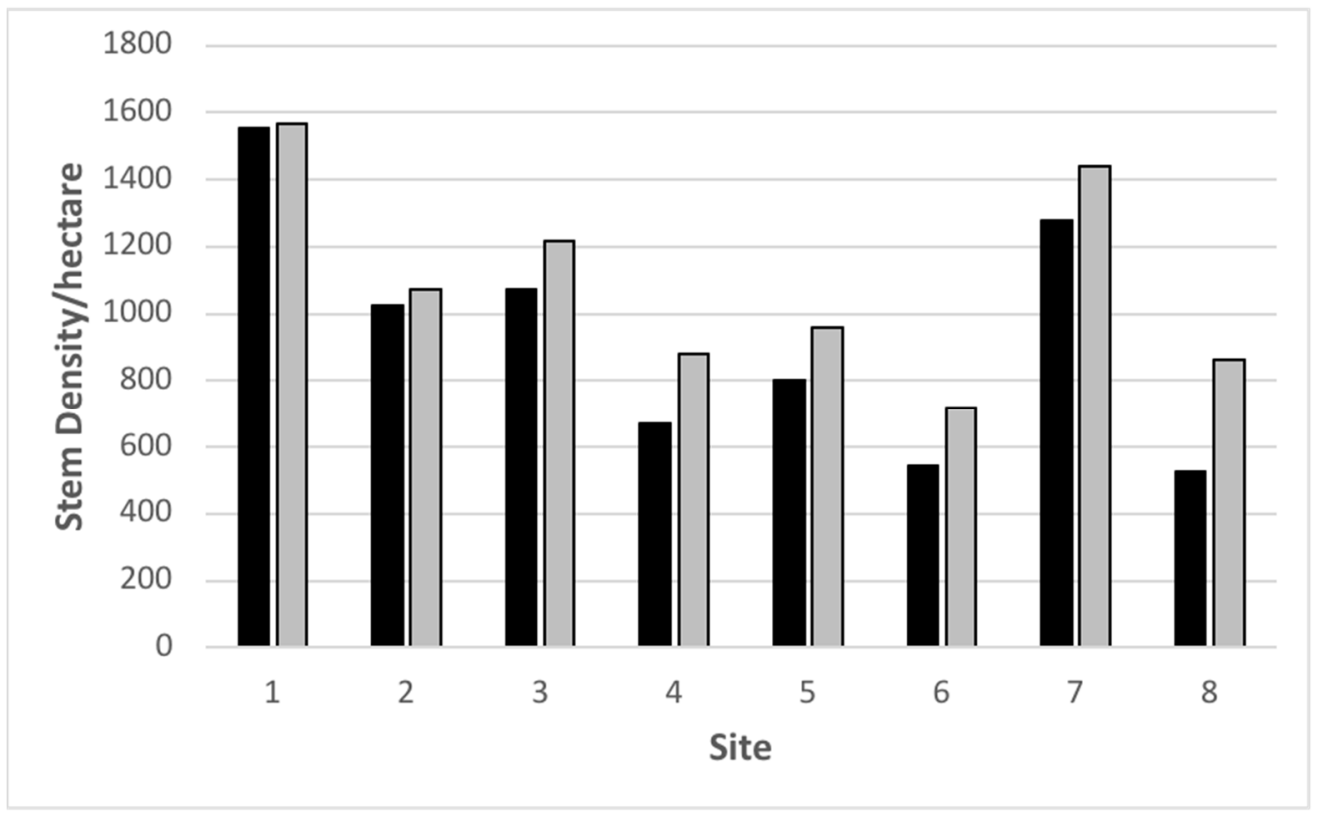

Figure 4. Overall stem density for Stations A (black) and B (gray) at Sites 1-8 in 2017.

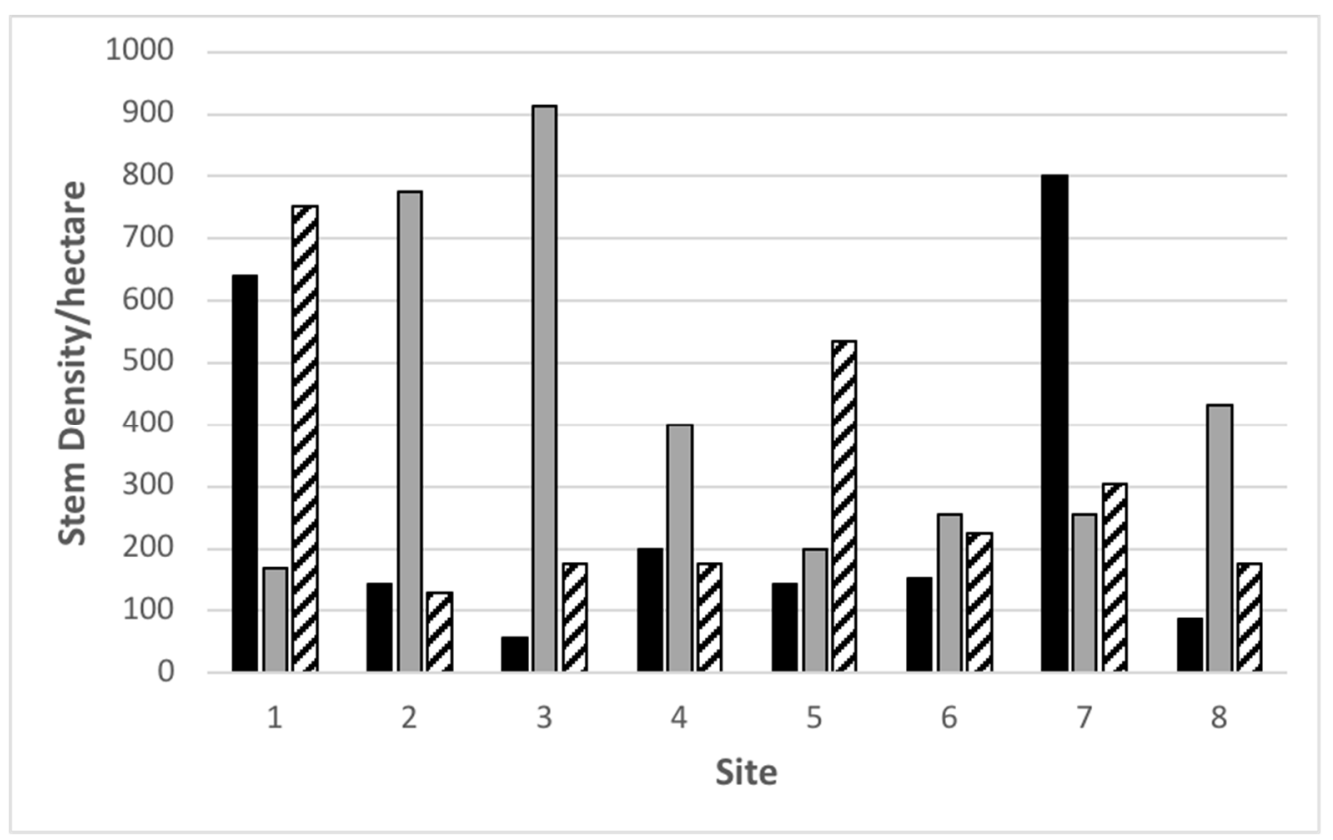

Figure 5. Stem density for the dominant midstory species midstory (black), and the two dominant canopy species Nyssa aquatica (gray) and Taxodium distichum (striped) at Sites 1-8 in 2017.

\subsection{Forest Function}

Percent canopy closure was nearly identical for 2016 and 2017 (Figure 6). During 2018-2020, canopy closure increased by $\sim 20$ percent $\left(\mathrm{F}_{4,280}=53.41, p<0.0001\right)$ demonstrating that the forest responded to the hydrologic restoration nearly instantaneously (Figure 6). 


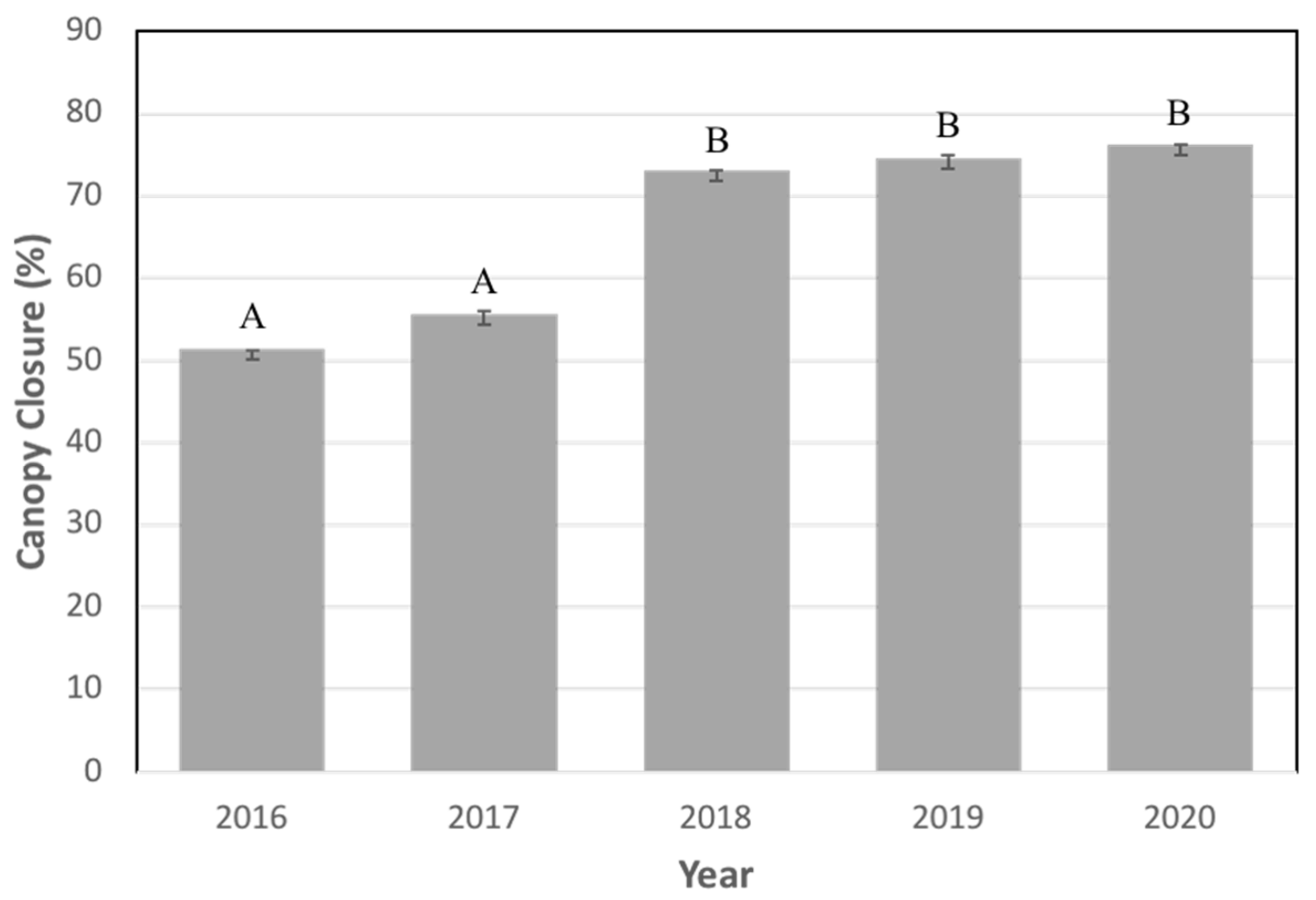

Figure 6. Percent canopy closure for 2016-2020. Bars that share letters are not statistically different according to Bonferroniadjusted mean comparison.

\subsubsection{Aboveground Wood Net Primary Production}

Aboveground wood net primary production differed across sites $\left(\mathrm{F}_{7,981}=3.69\right.$, $p=0.001$; Figure 7) and species $\left(F_{2,} 981=136.19, p<0.0001\right.$; Figure 8). Importantly, the reference site showed no change in wood NPP between 2017, 2018, and 2019, whereas all seven sites in the Lac des Allemands Swamp experienced a dramatic increase in 2018 (Figure 7), presumably caused by the hydrologic restoration (i.e., increased sheet flow and drainage). The increase in 2019 was not as large, presumably because the sites were far more flooded than during 2018; during 2018, the swamp was completely drained for nearly half of the growing season. All eight sites had their highest wood NPP in 2020. Pooled together, the 2018-2020 years had significantly higher diameter increases than the pre-project 2017 season (contrast $\mathrm{F}_{1,981}=11.86, p=0.001$ ).

Similarly, all three of the dominant species experienced increased aboveground wood net primary production in 2018 compared to 2017 (Figure 8). According to Bonferroniadjusted means, baldcypress had the greatest wood NPP, followed by water tupelo, and the midstory species had the least. Interestingly, the decreased productivity during 2019 compared to 2018 was primarily attributable to baldcypress (Figure 8). 


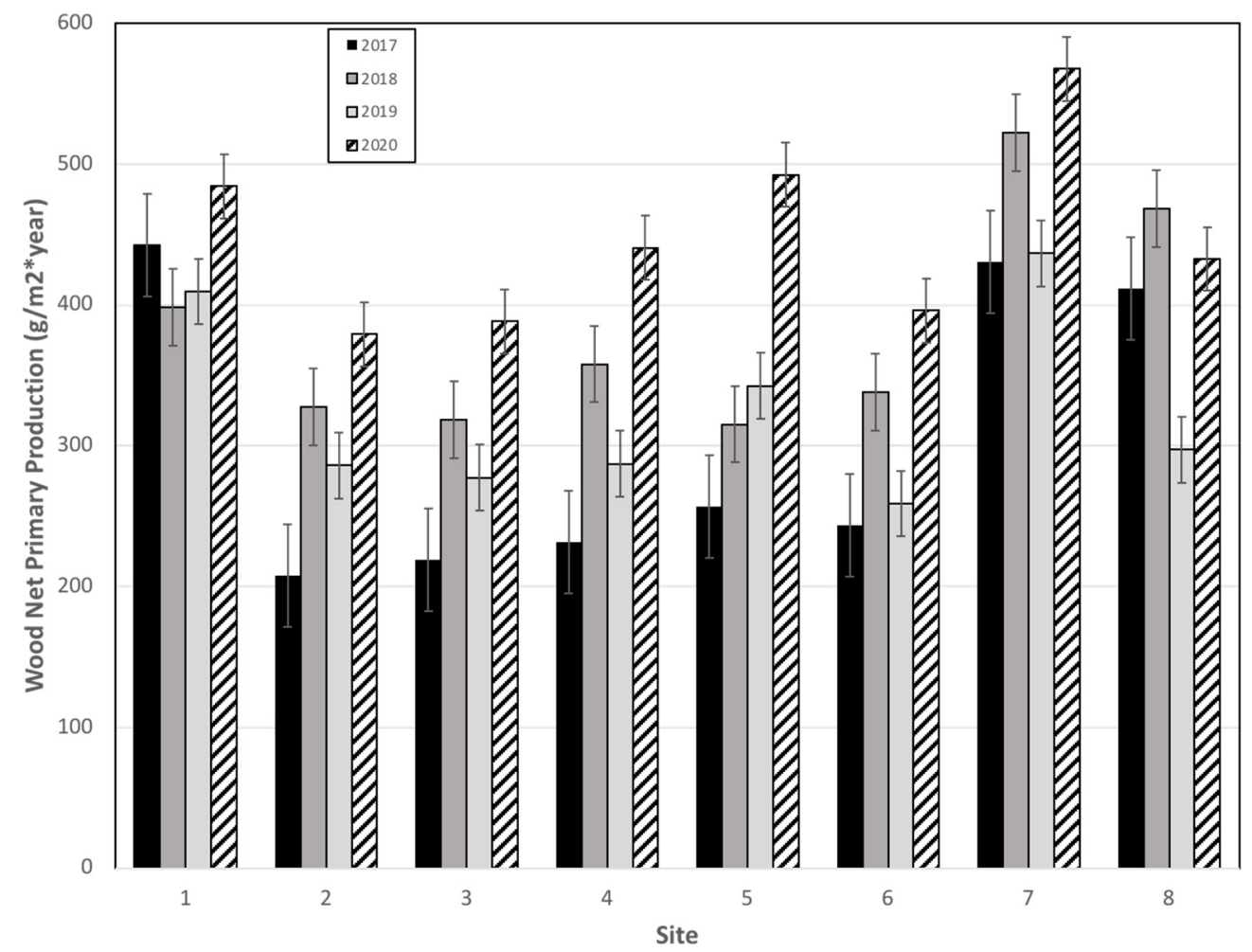

Figure 7. Net primary production (gm m ${ }^{-2} \mathrm{y}^{-1}+$ s.e.) for Sites 1-8 for 2017 (black), 2018 (dark gray), 2019 (light gray), and the 2020 (striped) growing seasons.

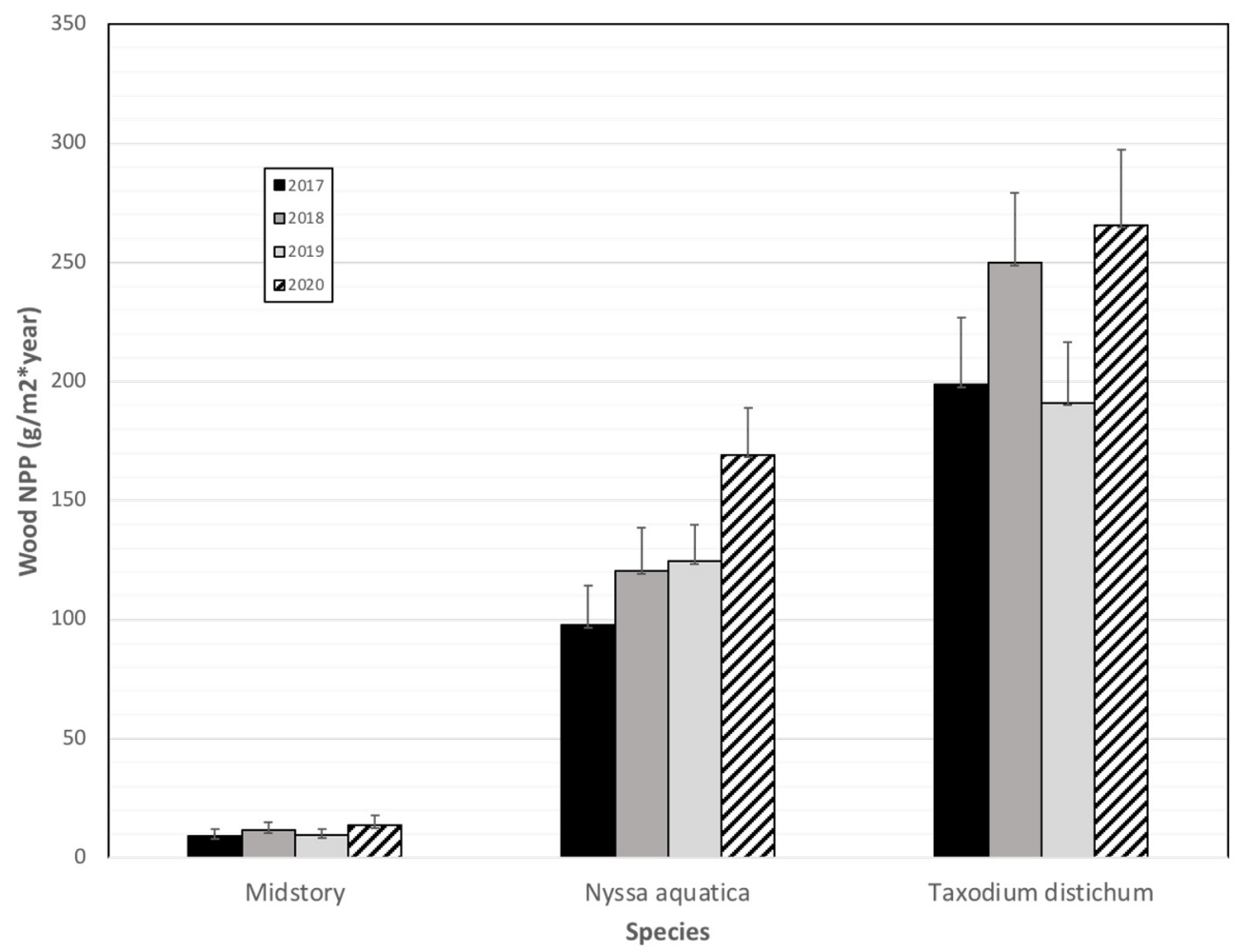

Figure 8. Net primary wood production $\left(\mathrm{gm} \mathrm{m}^{-2} \mathrm{y}^{-1}+\right.$ s.e.) for midstory species, Nyssa aquatica, and Taxodium distichum for 2017 (black), 2018 (dark gray), 2019 (light gray), and 2020 (striped) growing seasons. Midstory species were nearly all Acer rubrum var. drummondii. 


\subsubsection{Leaf Net Primary Production}

Leaf net primary production varied significantly across sites $\left(\mathrm{F}_{7,102}=2.14, p=0.046\right)$, but did not differ across years (Figure 9). Six of the seven Lac des Allemands swamp sites produced more leaf material in 2018 and 2019 than 2017. Tested together, 2018 and 2019, on average, produced a greater amount of leaf tissue than 2017 (contrast $F_{1,102}=5.31$, $p=0.023$ ). We believe that Hurricane Zeta removed substantial leaf litter in 2020 as our traps had oak litter from trees located over $200 \mathrm{~m}$ away; furthermore, 2020, in general, had the highest aboveground wood NPP and these two forms of primary production tend to track one another [14,15]. In addition, of the dependent variables, litterfall is the noisiest because of the (baldcypress) leafroller and the (water tupelo) forest tent caterpillar; during the first two litter collections each year, most of the tissue in the traps is reduced to the midribs of leaves.

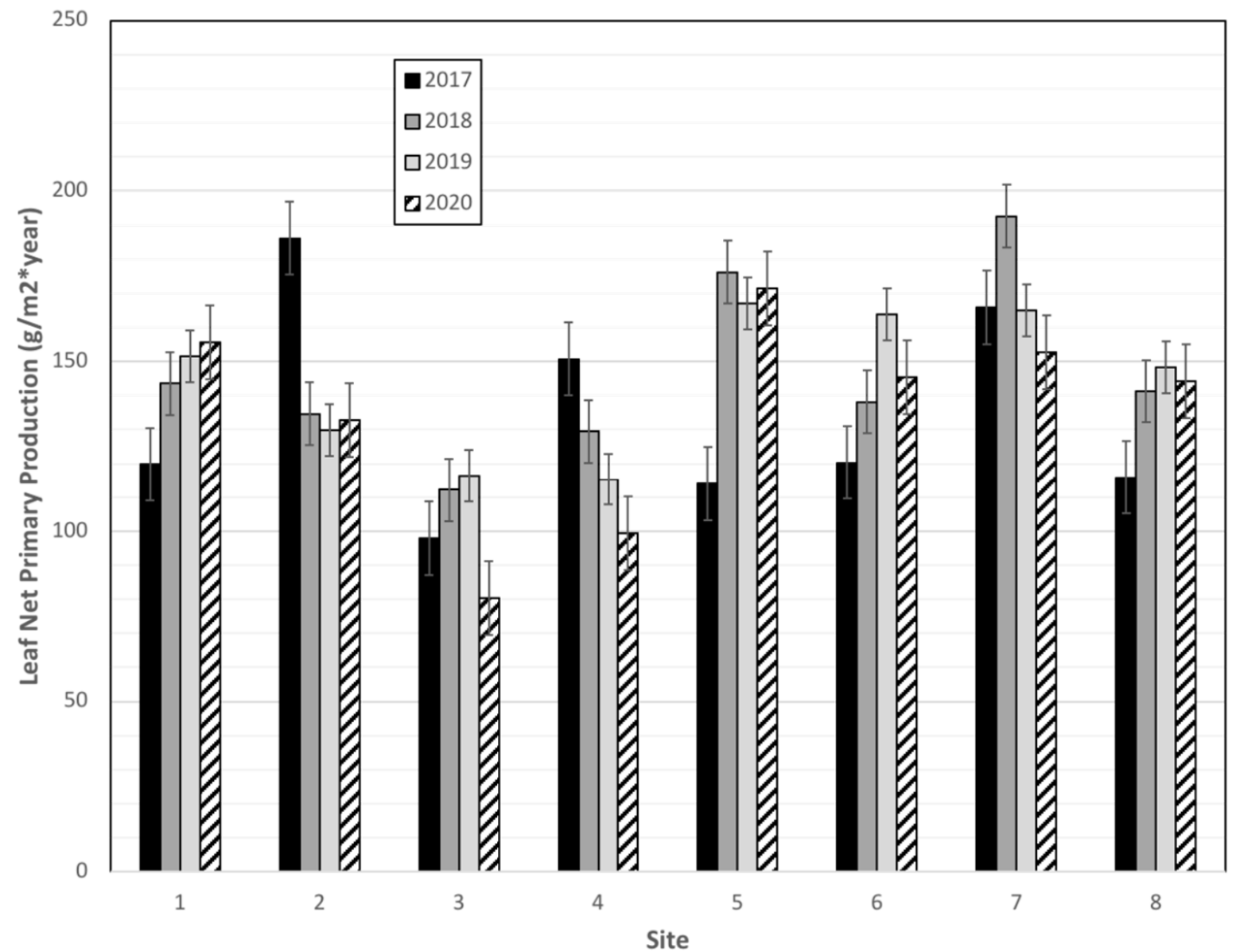

Figure 9. Leaf litter production ( $\mathrm{gm} \mathrm{m}^{-2} \mathrm{y}^{-1}+$ s.e.) for each site in the Lac des Allemands swamp during 2017 (black), 2018 (dark gray), 2019 (light gray), and 2020 (striped) as well as the reference site (Site 1).

Taxodium distichum produced far more leaf litter than Nyssa aquatica, and both produced far more litter than midstory species $\left(\mathrm{F}_{2,118}=257.85, p<0.0001\right.$; Figure 10). 


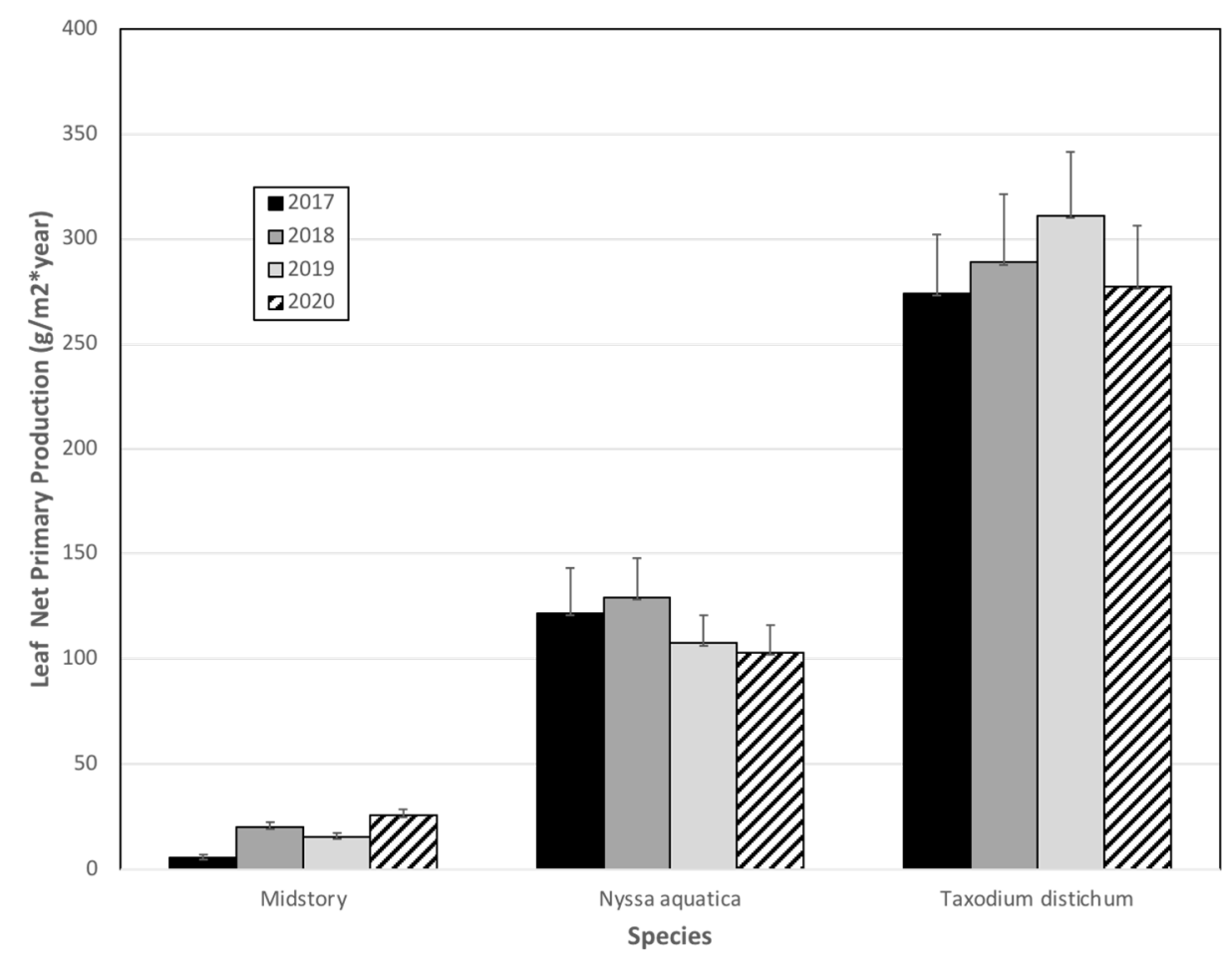

Figure 10. Leaf litter production (gm m $\mathrm{y}^{-2} \mathrm{y}^{-1}+$ s.e.) during 2017 (black), 2018 (dark gray), 2019 (light gray), and 2020 (striped) in the reference and Lac des Allemands swamp for the two canopy species (Taxodium distichum and Nyssa aquatica) and midstory species (nearly all of which are Acer rubrum var. drummondii).

\subsubsection{Total Aboveground Primary Production}

Total aboveground net primary production was obtained by summing wood and leaf production. In general, a clear trend of increased production occurred for the post-project construction years compared to 2017 (Figure 11). Post-project aboveground production was about half of that measured in the Lac des Allemands swamp in the mid-1970s [5,6], but comparable to that measured in the 1980s [7]. Aboveground production in the Lac des Allemands swamp is comparable to that of the healthiest sites in the Maurepas swamp and vastly greater than that of $87 \%$ of that swamp $[14,15]$. The distribution between leaf and wood production was remarkably similar within species types across years (Figure 12).

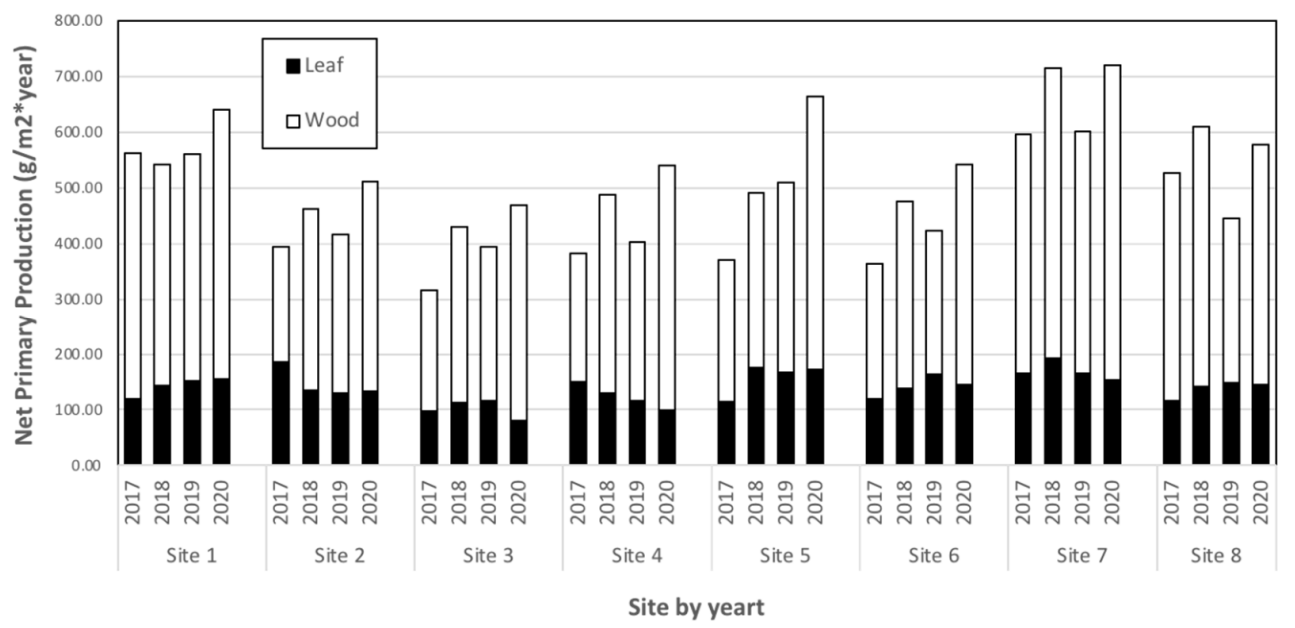

Figure 11. Total aboveground production $\left(\mathrm{gm} \mathrm{m}^{-2} \mathrm{y}^{-1}\right)$ across sites and year from 2017 to 2020. 


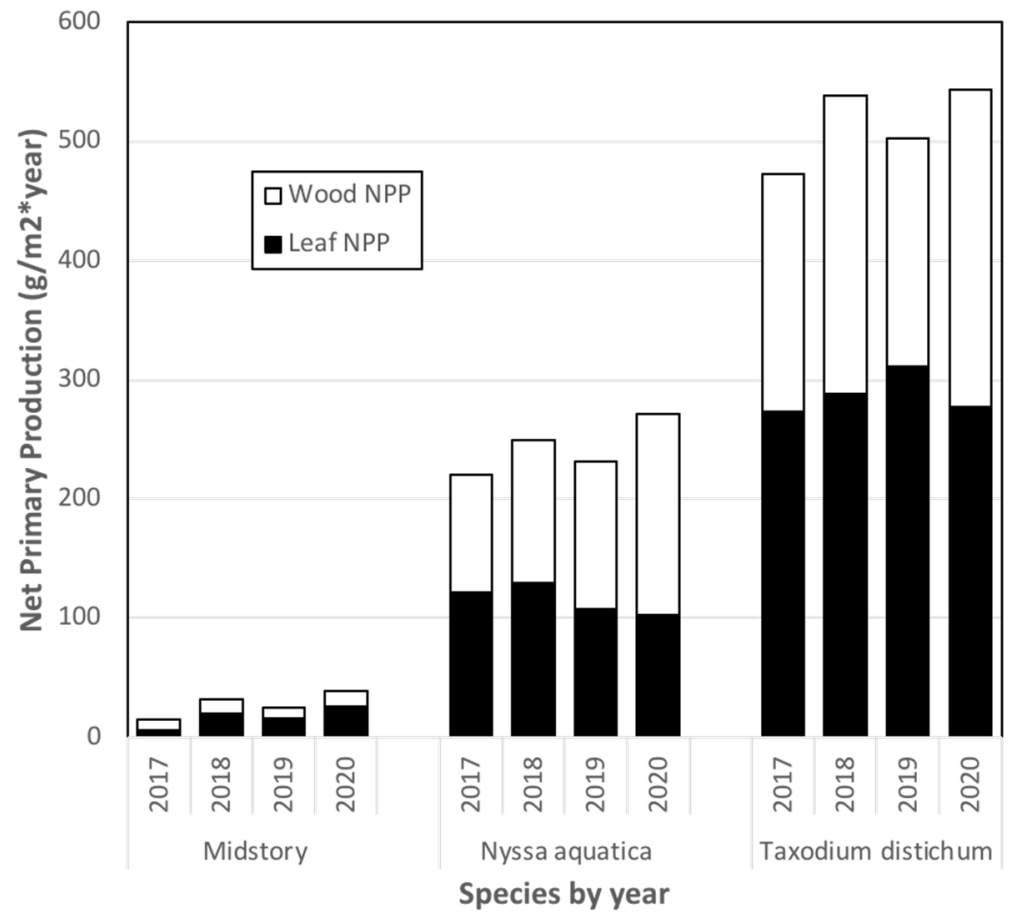

Figure 12. Total aboveground production $\left(\mathrm{gm} \mathrm{m}^{-2} \mathrm{y}^{-1}\right)$ across years for each species type.

\subsection{Natural Regeneration}

Natural regeneration of baldcypress and water tupelo has occurred every year since project completion (Figure 13). On average, approximately 200 seedlings germinate per hectare. During 2018 and 2019, baldcypress dominated recruitment, but far more water tupelo than baldcypress germinated in 2020. Many of these seedlings are now about $1 \mathrm{~m}$ tall.

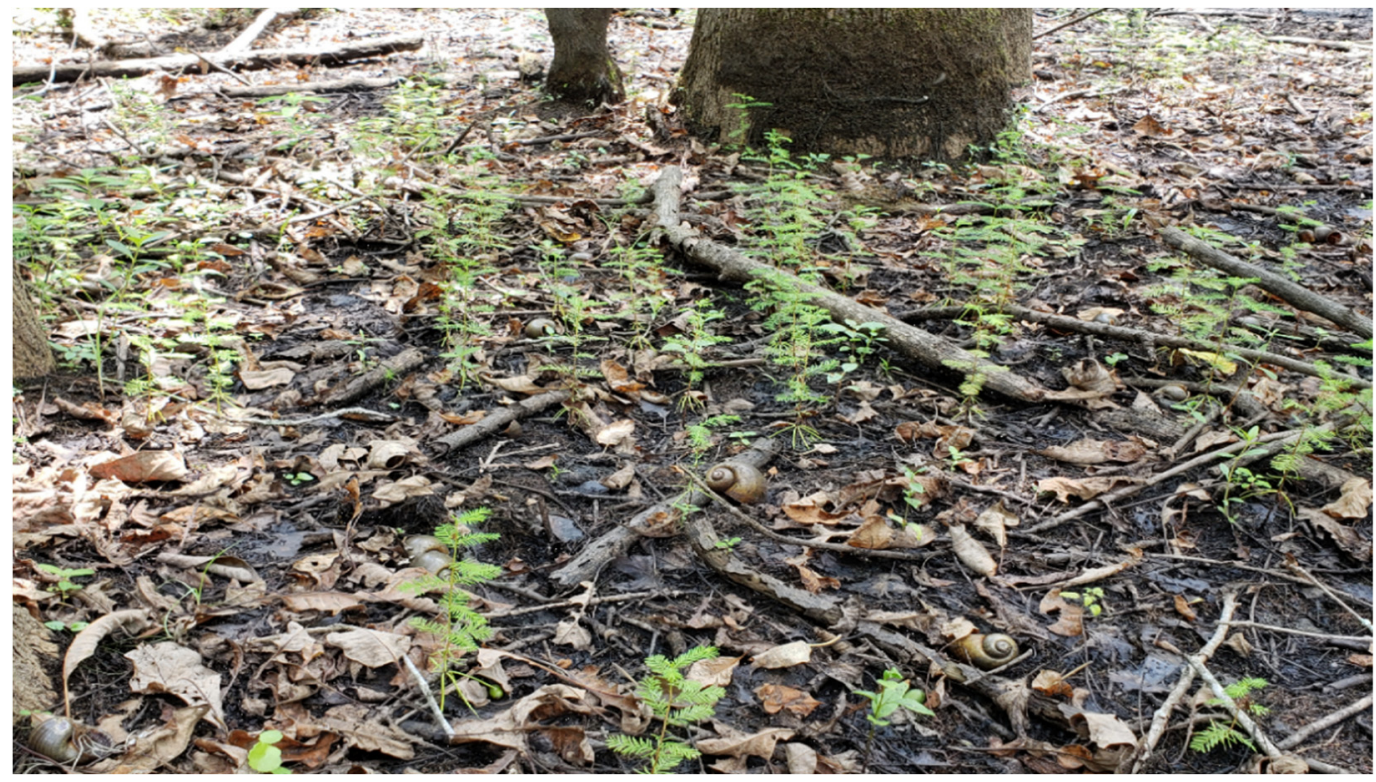

Figure 13. Seedling recruitment of bald cypress and water tupelo has occurred every year since project completion.

Granted that regular natural regeneration events now occur, perhaps the Lac des Allemands swamp is now sustainable. However, eustatic sea level rise in coastal Louisiana is $3.4 \mathrm{~mm}$ per year, subsidence averages $9 \mathrm{~mm} \mathrm{y}^{-1}\left( \pm 1 \mathrm{~mm} \mathrm{y}^{-1}\right.$ s.e.) [22], and water levels are rising [8]. The only restoration measures that are truly sustainable in coastal Louisiana 
deliver sediments that cause accretion to outweigh relative sea level rise. These are river re-introductions [23-26] and assimilation wetlands [27,28].

\subsection{Herbaceous Cover}

Herbaceous cover, by species, was estimated at all 64 herbaceous plots during fall of 2016 through 2020. The main pattern to date is that 2017 and 2018 were far more similar than 2016, 2019, and 2020, which also closely resembled one another on both axes (Figure 14A). The reference stations (Sites 1A and 1B) were originally dominated by Panicum gymnocarpon, but that species is no longer abundant. Overall, the Lac des Allemands project sites are dominated by Polygonum punctatum (Figure 14B). The loop-shaped trajectory of herbaceous cover is very clearly shown when the data are averaged for each year (Figure 15). Note that the pre-restoration years 2016 and 2017 map closely together on the $\mathrm{Y}$ axis as do post-restoration years 2018-2020. This is a clear indication of stagnant water (2016 and 2017) vs. sheet flow (2018-2020). By far the driest year was 2018, where Sites 2-8 had no standing water for nearly half of the growing season (Figure 16) and 2017 was also relatively dry. In contrast, these sites were flooded during all sample dates of 2016, 2019 , and 2020. These years also had high stage, which is presumably why the vegetation grouped together on the $\mathrm{X}$ axis for those years.

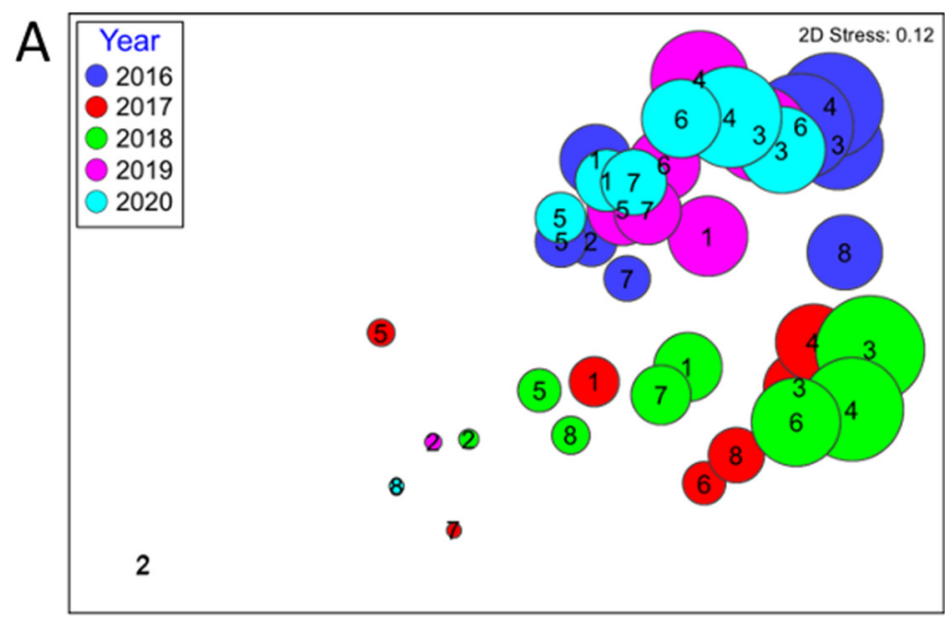

\section{B}

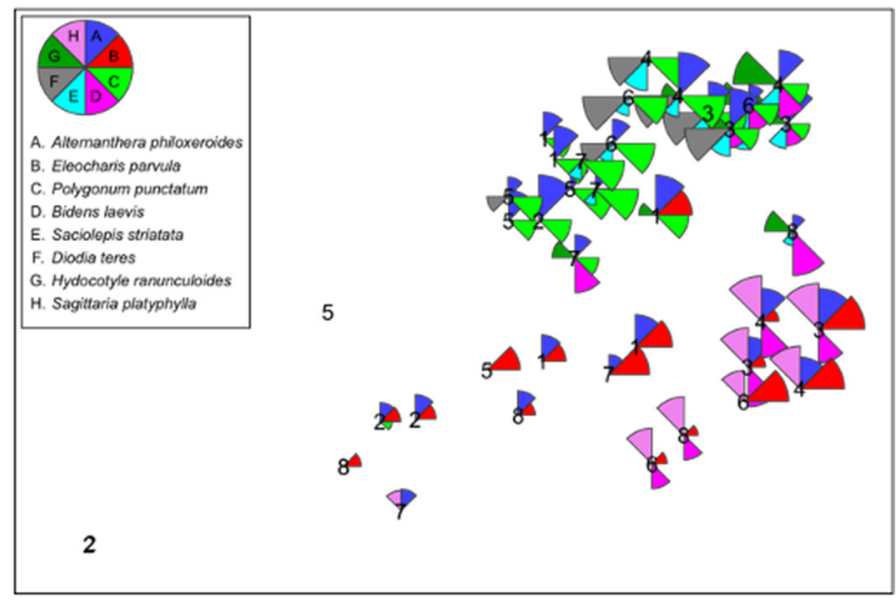

Figure 14. Percent cover of (A) all species and all years (bubble size represents relative total cover) and (B) the same ordination showing only the eight dominant herbaceous species (Alternanthera philoxeroides, Bidens laevis, Diodia teres, Eleocharis parvula, Hydrocotyle ranunculoides, Polygonum punctatum, Sagittaria platyphylla, and Sacciolepis striata). Pie slices reflect relative percent cover of the individual species. 


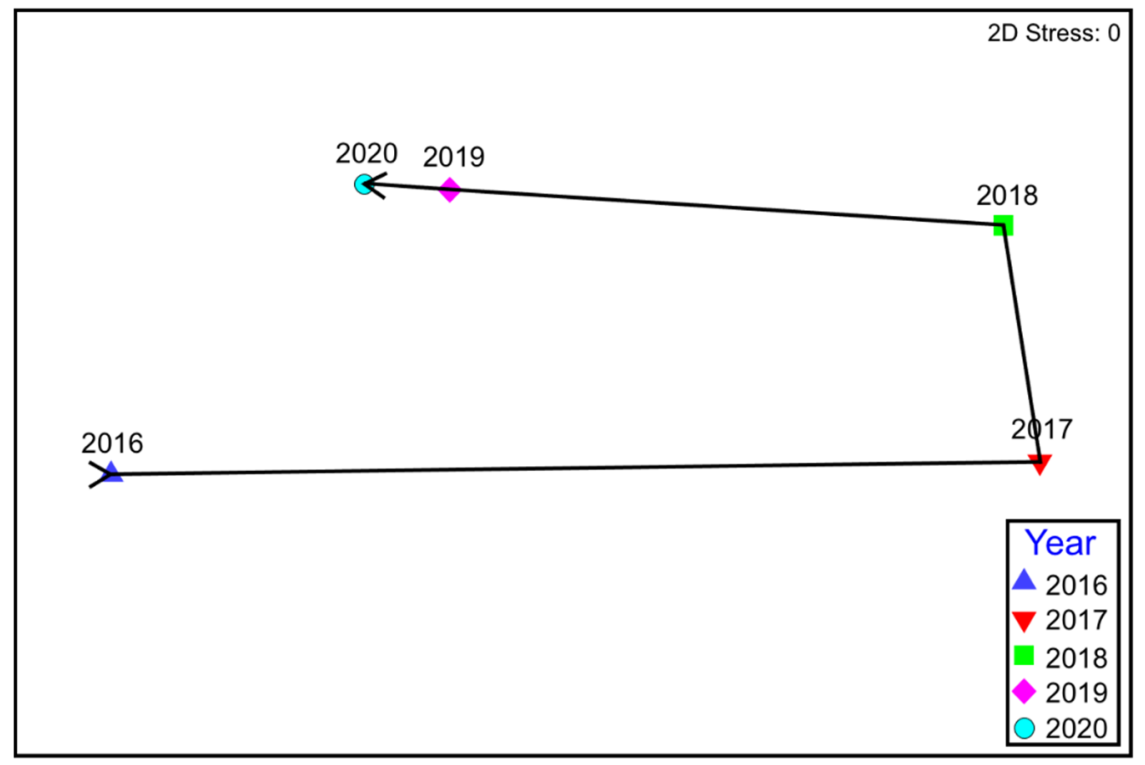

Figure 15. Average percent cover of all herbaceous species demonstrating the overall looped pattern from 2016 to 2020 .

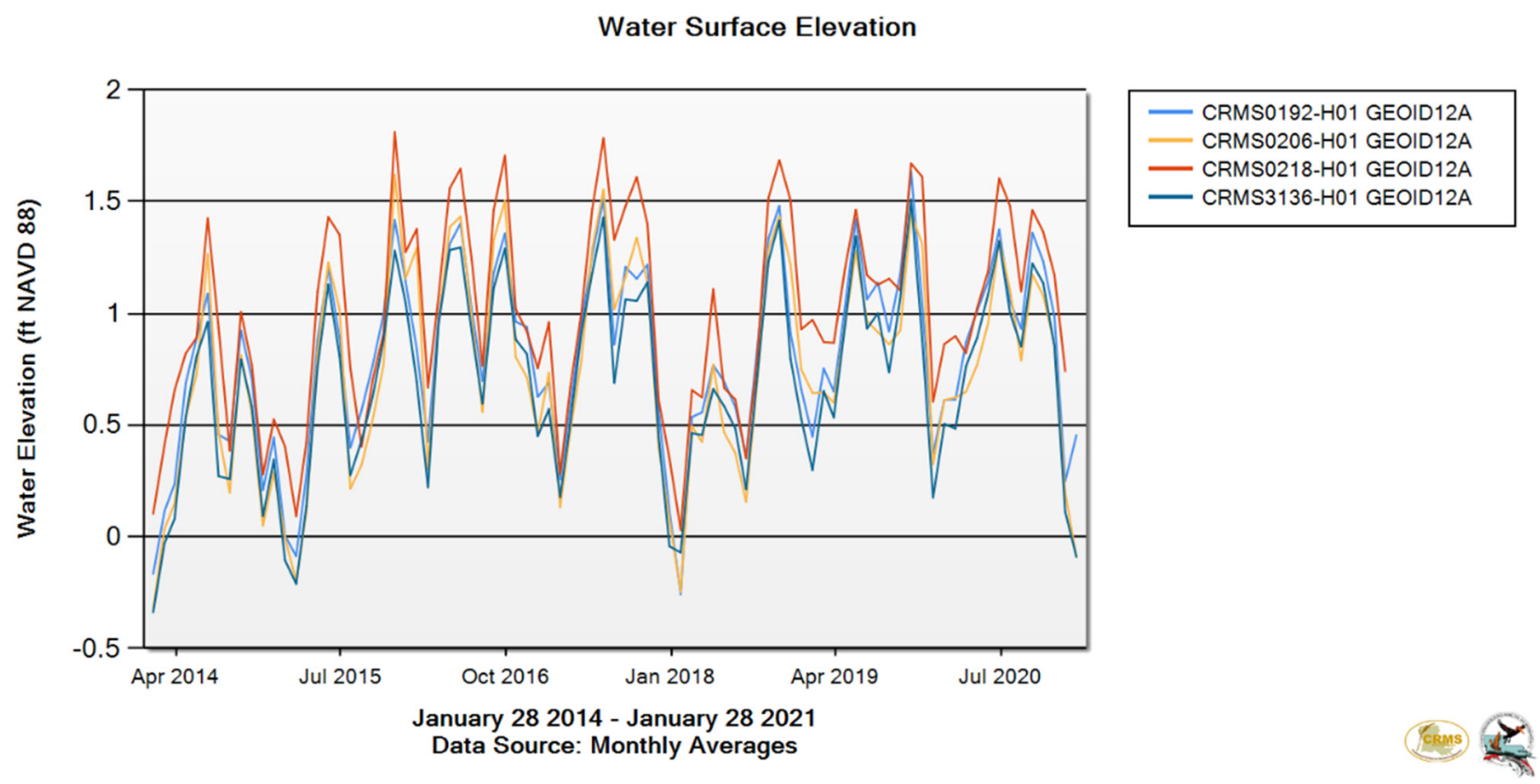

Figure 16. Stage gage records for four CRMS sites near Lac des Allemands swamp showing high water during 2016, 2019, and 2020 and very low water during 2018. The site with the highest stages depicts what the most flooded sites in Lac des Allemands swamp would look like prior to gapping.

\section{Conclusions}

This study was established to monitor the benefits of hydrologic restoration of an impounded baldcypress-water tupelo swamp in coastal Louisiana. Benefits were measurable within months of gap creation as canopy cover increased by $20 \%$ in 2018 . Hydrologic exchange has also increased aboveground wood and leaf production. Now that the natural hydrology has been restored, reliable periods of drawdown now occur during the spring, and these events have resulted in annual natural regeneration for the first time in 60 years. Thousands of hectares of impounded swamp exist in coastal Louisiana, and 
we have demonstrated that this technique is an extremely cost-effective means to enhance forest functions.

Author Contributions: The data were analyzed by G.P.S. and D.K. Most of the manuscript was written by G.P.S., however D.K., N.S., T.C. and G.C. provided help with conceptualization and edits. D.K. crafted all figures. G.P.S., D.K., N.S., T.C. and G.C. provided support in the field and laboratory. All authors have read and agreed to the published version of the manuscript.

Funding: The restoration plan for this project, known as the Hydrologic Restoration and Vegetative Planting in the Lac des Allemands Swamp (BA-34-2) was funded through the Coastal Wetlands Planning, Protection, and Restoration Act (CWPPRA).

Institutional Review Board Statement: Not applicable.

Informed Consent Statement: Not applicable.

Data Availability Statement: The forested and herbaceous data used for this article is stored in the coastal information management system database (CIMS) and can be accessed from the following link (https: / / cims.coastal.louisiana.gov / monitoring-data /, accessed on 26 June 2021).

Acknowledgments: The project is federally sponsored by the Environmental Protection Agency (EPA) and locally sponsored by the Coastal Protection and Restoration Authority of Louisiana (CPRA). We would like to take this opportunity to acknowledge Ken Teague of EPA, Jody Chenier, and Shane Landry of St. James Parish for their persistence in securing funding for this restoration project. We are grateful for the countless undergraduate and graduate students that helped us collect field data.

Conflicts of Interest: The authors declare no conflict of interest.

\section{References}

1. Chambers, J.L.; Conner, W.H.; Day, J.W.; Faulkner, S.P.; Gardiner, E.S.; Hughes, M.S.; Keim, R.F.; King, S.L.; McLeod, K.W.; Miller, C.A.; et al. Conservation, Protection and Utilization of Louisiana's Coastal Wetland Forests; Louisiana State University: Baton Rouge, LA, USA, 2005; 121p.

2. Coast 2050: Toward a Sustainable Louisiana: Louisiana Coastal Wetlands Conservation and Restoration Task Force; Louisiana Department of Natural Resources: Baton Rouge, LA, USA, 1998; 161p.

3. CPRA (Coastal Protection and Restoration Authority of Louisiana). Louisiana's Comprehensive Master Plan for a Sustainable Coast-2017 Draft Plan Release; CPRA: Baton Rouge, LA, USA, 2017; 169p.

4. Day, J.W.; Conner, W.H.; DeLaune, R.D.; Hopkinson, C.S.; Hunter, R.G.; Shaffer, G.P.; Kandalepas, D.; Keim, R.F.; Kemp, G.P.; Lane, R.R.; et al. A review of 50 years of study of hydrology, wetland dynamics, aquatic metabolism, water quality and trophic status, and nutrient biogeochemistry in the Barataria Basin, Mississippi Delta-System functioning, human impacts and restoration approaches. Water 2021, 13, 642. [CrossRef]

5. Conner, W.H.; Day, J.W. Productivity and composition of a baldcypress-Water tupelo swamp site and a bottomland hardwood site in a Louisiana swamp. Am. J. Bot. 1976, 63, 1354-1364. [CrossRef]

6. Conner, W.H.; Gosselink, J.G.; Parrondo, R.T. Comparison of the vegetation of three Louisiana swamp sites with different flooding regimes. Am. J. Bot. 1981, 68, 320-331. [CrossRef]

7. Conner, W.H.; Day, J.W. Water level variability and litterfall productivity of forested freshwater wetlands in Louisiana. Am. Midl. Nat. 1992, 128, 237-245. [CrossRef]

8. Conner, W.H.; Day, J.W. Rising water levels in coastal Louisiana: Implications for two coastal forested wetland areas in Louisiana. J. Coastal Res. 1988, 4, 589-596.

9. DuBarry, A.P. Germination of bottomland tree seed while immersed in water. J. For. 1963, 61, $225-226$.

10. Harms, W.R. Some effects of soil type and water regime on growth of tupelo seedlings. Ecology 1973, 54, 188-193. [CrossRef]

11. Myers, R.S.; Shaffer, G.P.; Llewellyn, D.W. Baldcypress (Taxodium distichum (L.) Rich.) restoration in southeast Louisiana: Relative effects of herbivory, flooding, competition, and macronutrients. Wetlands 1995, 15, 141-148. [CrossRef]

12. Souther, R.F.; Shaffer, G.P. The effects of submergence and light on two age classes of baldcypress (Taxodium distichum (L.) Rich.) seedlings. Wetlands 2000, 20, 697-706. [CrossRef]

13. Williston, H.L.; Shropshire, F.W.; Balmer, W.E. Cypress Management: A Forgotten Opportunity, Forestry Report SA-FR8; USFS-S\&PF: Atlanta, GA, USA, 1980.

14. Shaffer, G.P.; Wood, W.B.; Hoeppner, S.S.; Perkins, T.E.; Zoller, J.A.; Kandalepas, D. Degradation of baldcypress-water tupelo swamps to marsh and open water in southeastern Louisiana, U.S.A.: An irreversible trajectory. J. Coast. Res. 2009, 54, 152-165. [CrossRef]

15. Shaffer, G.P.; Day, J.W.; Kandalepas, D.; Wood, W.B.; Hunter, R.G.; Lane, R.R.; Hillmann, E.R. Decline of the Maurepas Swamp, Pontchartrain Basin, Louisiana, and approaches to restoration. Water 2016, 8, 101. [CrossRef] 
16. Delaune, R.D.; Buresh, R.J.; Patrick, W.H., Jr. Relationship of soil properties to standing crop biomass of Spartina alterniflora in a Louisiana marsh. ECMS 1979, 8, 477-487. [CrossRef]

17. Hatton, R.S. Aspects of Marsh Accretion and Geochemistry: Barataria Basin, Louisiana. Master's Thesis, Louisiana State University, Baton Rouge, LA, USA, 1981; 116p.

18. Messina, M.G.; Conner, W.H. (Eds.) Southern Forested Wetlands: Ecology and Management; Lewis Publishers: New York, NY, USA, 1998; 640p.

19. Clark, A.; Phillips, D.R.; Frederick, D.J. Weight, Volume, and Physical Properties of Major Hardwood Species in the Gulf and Atlantic Coastal Plains. USDA Forest Service Research Paper SE-250; Southeastern Forest Experimental Station: Ashville, NC, USA, 1985.

20. Muzika, R.M.; Gladden, J.B.; Haddock, J.D. Structural and functional aspects of succession in southeastern floodplain forests following a major disturbance. Am. Midl. Nat. 1987, 117, 1-9. [CrossRef]

21. Scott, M.L.; Sharitz, R.R.; Lee, L.C. Disturbance in a cypress-tupelo wetland: An interaction between thermal loading and hydrology. Wetlands 1985, 5, 53-68. [CrossRef]

22. Nienhuis, J.H.; Tornqvist, T.E.; Jankowski, K.L.; Fernandes, A.M.; Keogh, M.E. A new subsidence map for coastal Louisiana. GSA Today 1998, 27, 58-70.

23. Day, J.W., Jr.; Shaffer, G.P.; Britsch, D.; Reed, D.; Hawes, S.; Cahoon, D. Pattern and process of land loss in the Louisiana coastal zone: An analysis of spatial and temporal patterns of wetlands habitat change. Estuaries 2000, 23, 425-438. [CrossRef]

24. Day, J.W.; Hunter, R.; Keim, R.; DeLaune, R.; Shaffer, G.P.; Evers, E.; Reed, D.; Brantley, C.; Kemp, G.P.; Day, R.; et al. Ecological response of forested wetlands with and without large-scale Mississippi River input: Implications for management. Ecol. Eng. 2012, 46, 57-67. [CrossRef]

25. Day, J.W.; Lane, R.R.; D’Elia, C.F.; Wiegman, A.R.H.; Rutherford, J.S.; Shaffer, G.P.; Brantley, C.G.; Kemp, G.P. Large infrequently operated river diversions for Mississippi Delta restoration. ECSS 2000, 183, 292-303.

26. Rutherford, J.S.; Day, J.W.; D’Elia, C.F.; Wiegman, A.R.H.; Willson, C.S.; Caffey, R.H.; Shaffer, G.P.; Lane, R.R.; Batker, D. Evaluating trade-offs of a large infrequent sediment diversion for restoration of a forested wetland in the Mississippi Delta. Coast. Shelf Sci. 2018, 203, 80-89. [CrossRef]

27. Shaffer, G.P.; Day, J.W.; Hunter, R.G.; Lane, R.R.; Lundberg, C.J.; Wood, W.B.; Hillmann, E.R.; Day, J.N.; Strickland, E.; Kandalepas, D. System response, nutria herbivory, and vegetation recovery of an assimilation wetland in coastal Louisiana. Ecol. Engin. 2015, 79, 120-131. [CrossRef]

28. Hunter, R.G.; Day, J.W.; Lane, R.R.; Shaffer, G.P.; Day, J.N.; Conner, W.H.; Rybczyk, J.M.; Mistich, J.A.; Ko, J.Y. Using natural wetlands for municipal effluent assimilation: A half century of experience for the Mississippi River Delta and surrounding environs. In Multifunctional Wetlands: Pollution Abatement and Other Ecological Services from Natural and Constructed Wetlands; Nagabhatla, N.N., Metcalfe, C.D., Eds.; Springer: Basel, Switzerland, 2018; pp. 15-81. 